Meta

Journal des traducteurs

Translators' Journal

\title{
New Cognitive Approaches in Process-Oriented Translation Training
}

\section{Hannelore Lee-Jahnke}

Volume 50, numéro 2, avril 2005

Processus et cheminements en traduction et interprétation Processes and Pathways in Translation and Interpretation

URI : https://id.erudit.org/iderudit/010942ar

DOI : https://doi.org/10.7202/010942ar

Aller au sommaire du numéro

Éditeur(s)

Les Presses de l'Université de Montréal

ISSN

0026-0452 (imprimé)

1492-1421 (numérique)

Découvrir la revue

Citer cet article

Lee-Jahnke, H. (2005). New Cognitive Approaches in Process-Oriented

Translation Training. Meta, 50(2), 359-377. https://doi.org/10.7202/010942ar
Résumé de l'article

Après une brève description de l'état de la question dans ce domaine, cet article présente de nouvelles approches dans l'enseignement de la traduction qui sont centrées sur les processus. Les différents instruments utilisés lors des séminaires, tels que des questionnaires ou des logiciels ainsi que les résultats obtenus avec ces méthodes, constituent le point central de cet article. La troisième et dernière partie esquisse les résultats préliminaires d'un projet de recherche interdisciplinaire mené avec le département de neurologie de l'Hôpital Cantonal de Genève ainsi que les possibilités envisagées de mettre en application les " dérivées » ou les retombées de cette recherche en didactique de la traduction. 


\title{
New Cognitive Approaches in Process-Oriented Translation Training
}

\author{
HANNELORE LEE-JAHNKE \\ University of Geneva, Geneva, Switzerland \\ hannelore.lee-jahnke@eti.unige.ch
}

\begin{abstract}
RÉSUMÉ
Après une brève description de l'état de la question dans ce domaine, cet article présente de nouvelles approches dans l'enseignement de la traduction qui sont centrées sur les processus. Les différents instruments utilisés lors des séminaires, tels que des questionnaires ou des logiciels ainsi que les résultats obtenus avec ces méthodes, constituent le point central de cet article. La troisième et dernière partie esquisse les résultats préliminaires d'un projet de recherche interdisciplinaire mené avec le département de neurologie de l'Hôpital Cantonal de Genève ainsi que les possibilités envisagées de mettre en application les «dérivées » ou les retombées de cette recherche en didactique de la traduction.
\end{abstract}

\section{ABSTRACT}

After a brief description of the state of the art, this paper presents new methods of process-oriented translation training. The different instruments used in class, such as questionnaires and other tools, the learning outcome of these methods and the improvement of proficiency achieved by these means, constitute the core of the paper. The third and final part deals with the preliminary results of an interdisciplinary research project with the Department of Neurology of the University Hospital of Geneva, and the prospects for applying this type of research to translation training.

\section{MOTS-CLÉS/KEYWORDS}

cognitive approaches in didactics, translation processes, interdisciplinary research, course concept, inferential activity

«Chaque langue construit un monde particulier dont la singularité est souvent irréductible à tout autre.»

Philippe Descamps (2004: 154-160)

\section{Introduction}

Cognitive approaches to translation mechanisms and in particular process-oriented studies (Königs 1996) have been examined intensely for the past decades (Krings 1986, Séguinot 1989, Tirkkonen-Condit 1989, Jääskeläinen 1987, Lee-Jahnke 1998) and more recently (Houdé et al. 2003; Driven \& Verspoor 2004; Paradis 2004; Wildgen 2004). They offer more insight into what goes on in the translator's mind. Before we briefly review the state of the art, it is necessary however to clarify two points. First, is the cognitive approach in translation studies mainly or merely a fashion or sign of our times? Second, how intimately is this approach linked to the cognitive approach in linguistics? 


\section{Cognitive approaches in translation studies: A new fashion?}

The fact that thinking and language can only function together was already pointed out by Parmenides ${ }^{1}$ and was developed further in the Middle Ages and in the 17th century. ${ }^{2}$ In the mid-20th century the hypothesis of linguistic relativity, often called the Sapir-Whorf hypothesis, ${ }^{3}$ reversed the relation between language and thinking. According to the determinism movement, an extreme version of the Sapir-Whorf hypothesis, language completely determines the thinking of human beings. We disagree, but believe that language and thinking influence each other. But what are the main functions of thinking? First, according to Peirce (1931-1935), it is to produce habits to act in a certain way to allow the person concerned to adapt himself or herself to the environment. Second, thinking presupposes the existence of mental entities, of representations in the mind. ${ }^{4}$ The answer to our first question is therefore that there is certainly an increased interest today in the cognitive exploration of language $^{5}$ and linguistics, but we must also bear in mind that there are attempts to explain nearly every learning process or behaviour these days through cognitive sciences.

\subsection{How intimately is this approach linked to the cognitive approach in linguistics?}

To be able to answer this question, we have to look at how language not only enables communication, but also reflects mankind's conceptual world. This is a complex matter, as the conceptual world consists, among other things, of conceptual categories, ${ }^{6}$ which are far richer than the system of linguistic signs.

Many, but not all, conceptual categories give rise to linguistic categories, which enable us not only to communicate, but also to guide our understanding of the world. Psycholinguistics, defined by Aitchison (1992: 73) as the study of the language and the mind, is a fairly young discipline, which should not be confounded with language psychology. It was created through collaboration between psychologists and linguists. Although their disciplines were already well defined, both had one aim in common: the thorough study of language. Hence, psycholinguistics was created intentionally by a group of specialists in $1951 .^{7}$ As psychologists, cognitive scientists and linguists created this new discipline, listed all the problems to be dealt with and aimed at making a synthesis between psychology and learning processes and linguistics (Peterfalvi 1974), it is obvious that the cognitive approach in linguistics and translation studies is intimately linked. This will be our starting point to highlight new methods of process-oriented translation training with opportunities for the future if we take into account Ladmiral's research (1999). ${ }^{8}$

\subsection{Process-oriented translation training}

\subsubsection{Some historical aspects}

Translation studies have long focused mainly on the product and much less on the process. This seems understandable, as this young discipline had to define in the first place what the product should be and only in a second step how to reach this objective. But a closer look at history ${ }^{9}$ shows us that, for as long as there have been translations, the translators, who did not necessarily see themselves as such, have reflected 
on the best way of translating. ${ }^{10}$ Think, for instance, of the discussions on how literal and how free a translation should or can be. ${ }^{11}$ At this point, theories were developed. They aimed at justifying the way a text was translated and also at explaining certain problems linked to translation. The dichotomy between word and sense $e^{12}$ and free and literal has been at the heart of the debate for centuries.

The shift from product to process came with a more intensive training of translators. It is this approach which can help to improve quality through a better understanding of the different ways - processes - of obtaining the quality of the final product. An interesting task for trainers might be to collect data ${ }^{13}$ from their learners in order to follow the optimal pathways that they used to reach their aim and try to find out which patterns ${ }^{14}$ lead to the best translation.

Such data can help develop new methods in translation teaching and training of trainers. Hence, a great deal of empirical research needs to be done. To sum up, during the past twenty years scientific psychology has evolved rapidly and the debate between behaviourism and mentalism ${ }^{15}$ has led to a new problem: where is information treated ${ }^{16}$ and how? This problematic is characterized by a shift in the study from functions and faculties to the study of the extent to which the context and the situation in which a task has to be handled are important. This is also the reason why mental representations nowadays play an increased role in translation studies. Instead of searching for general laws, one tends to look for mechanisms underlying the functioning of the learning process. The future will show whether this way of proceeding is the right one. Bearing the above in mind, we can set out our course concept.

\section{Course concept: preliminary thoughts}

\subsection{Three axes in didactics}

We all know the didactic triangle which places student, knowledge and professor each on one angle. Sometimes the emphasis is on the learning process - between student and knowledge - sometimes on the training process - between professor and student, and, last but certainly not least, on the teaching process - between professor and knowledge. Class activities differ according to which of these processes prevails. ${ }^{17}$ For our purposes in this presentation, we would like to visualize these processes with arrows and add that, in a well thought-out course, all three axes have to be taken into consideration. Which of the axes should be given more attention depends largely on the group of students and the stage of their studies.

I) PROFESSOR

TRAINING PROCESS

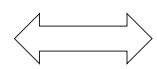

II) KNOWLEDGE

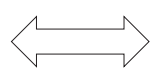

III) PROFESSOR
TEACHING PROCESS
STUDENT

STUDENT

KNOWLEDGE

As these axes will guide us in the way we structure our courses at a given stage, we will have first to elucidate the students encyclopaedic knowledge, and second to 
make a follow up of their way of working, i.e. the strategies they use while translating. We know that, for instance, teamwork favours autonomous and continuous learning and, within teamwork, peer teaching should be included in a course, if we want our students to get the maximum benefit from their training. ${ }^{18}$

\subsection{How information is treated}

Our starting point for the course concept can therefore be the pattern developed by Prégent (1990) which clearly shows the different levels of consciousness activated through different types of activities. There it becomes obvious that more responsibility given to students through project teaching will definitely increase their ability to infer their learned knowledge and to apply it again in similar situations. Where we see a problem, however, is that some repetition ${ }^{19}$ is needed, which very often, due to lack of time in a training programme, cannot be dealt with satisfactorily. But, in translation, repetition is not only a problem of time: in our type of activity it is difficult to repeat exactly the same thing, unlike experiments in other fields.

\subsection{Project teaching}

According to our own teaching experience, projects not only motivate students, but also help them to work in a more process-oriented way:

- The objective of the task will help them choose;

- The selection of translation strategies will be more appropriate if the constraints imposed are more precise;

- In order to achieve maximum effect in autonomous learning and responsibilization, the task should ideally be linked to an environmental or learning context with which the students are familiar. ${ }^{20}$

\subsection{Importance of mental representations in the learning process}

The term mental representation is defined as the structure and representation of knowledge in so-called "mental models" (Rickheit \& Strohner 1993). For our purposes it is important that these models are "reduced" models and can never be complete, but are always partial. Like any other model in real life, each person has his or her own construct. Cognitive models and mental representations can be dealt with in the same way. The proof for this interpretation can be seen in the intra-individual analysis of a text to be translated: the same subject may make a different interpretation after having experienced other things in life. ${ }^{21}$ The most explicit examples for this are fairy tales. They can be read and read again and will always evoke in the reader a different interpretation. Bruno Bettelheim (1977) used this type of text for his very important book "Kinder brauchen Märchen." 22

Translators, whose job it is to interpret texts day after day, are no exception. They have their own world knowledge, ${ }^{23}$ but maybe, because of their professional activity, they know that their understanding of the text is only a subjective one and will always remain very personal. What they do, or at least what they should do, is compensate for this subjective understanding through intensive research in order to get as close to the original as possible and, hence, become as objective as possible. 
As the theoretical approach to translation studies increasingly looks at cognitive aspects, it is astounding that the core of cognition, i.e. representations, has so far been neglected in this kind of research, particularly if we take a closer look at the definition of mental representations:

"Mental representations are patterns of organization which comprise the knowledge of the individual, processes of changing this knowledge, deriving new knowledge through conscious and unconscious inferences and generating new activity plans." ${ }^{25}$ Representation is probably the most important among all theoretical concepts of the cognitive studies which aim at explaining human behaviour. ${ }^{26}$ And one of the central points is the link between language and mental representations. ${ }^{27}$ It is therefore easy to understand why we translate better and differently when we have more knowledge of the subject matter. It is true, too, that representations may be misleading when the mental imaging is very powerful and corresponds to a different original "input" of the subject. This should be made clear in translation classes.

Representations have become a buzzword in cognitive sciences and are increasingly subject to examination. Why are they so important? They are the cognitive context in which information is treated. Normally, representations are transitory because the processing is linked to a task and a new task generates new representations. Some representations may become part of the long-term memory as knowledge, or stereotypes, and some processing can be stored as procedures.

In translation classes we deal mainly with symbolic information, e.g. words and icons. In order to "process" this type of information, our brain works mainly with the activation of knowledge and representations, attribution of significance and production of inferences. This leads to interpretations which, in turn, lead to actions, new knowledge or communication.

\subsection{Some Components of Learning - Mechanisms}

The different mechanisms that play a major role in the learning process are:

Inference; Judgement; Diagnostic ability; Reasoning by analogy.

One of the general objectives of translation classes should be the stimulation of these mechanisms in order to improve the translation process. One can note for example the following:

\subsubsection{How to enhance inferential activity}

As any learner is able to add new information on existing information, we have to use this capacity in the training process. These inferential activities, as they are called, are composed of two major elements:

a) Deduction: this is an inference that aims at getting a truthful conclusion, starting from one or more premises known to be correct. This deductive capacity can be stimulated among others with the questionnaire ${ }^{28}$ that we ask students to fill in with each translation, and which offers 3 strategies to solve problems: in this particular case, the socalled default strategy. ${ }^{29}$ The deductive activity of the human brain is characterized by two processes: ${ }^{30}$ the heuristic process, which selects the information which we consider to be pertinent, and the analytic process, which then analyses this information. ${ }^{31}$ 
b) Induction: this inferential procedure is based on particular premises which worked well in other circumstances and aims at applying them in a more general way. The learner knows, however, that he/she cannot be absolutely certain about the best possible result. $^{32}$

\subsubsection{How to enhance judgement}

Normally two types of judgement can be distinguished: a) evaluative judgement, where the individual expresses his/her preferences, and which plays a major role in translation activities; and b) predictive judgement, in which the individual forecasts his/her choice.

\section{a) Evaluative judgement}

This type of judgement should be stimulated during the complete process of formative evaluation. ${ }^{33}$ Normally, this judgement is characterized by a choice of options which can be put into a hierarchical order or not. ${ }^{34} \mathrm{~A}$ hierarchical order, however, is very helpful in making a more objective choice and hence in improving the abilities of the learners. ${ }^{35}$ It is well known that the normal process of cognition and motricity requires a certain organization and order. And in all situations where a certain order is necessary, decisions have to be made and, to be able to make these decisions, criteria have to be established.

b) Predictive judgement

This type of judgement is based on probabilities which, in turn, go back to experience. It is normally found in more advanced learners or professionals, where it can also be linked to automatisms.

\subsubsection{Diagnostic activities}

What do we mean exactly by this very complex term diagnostic? We tend to agree with Rasmussen (1986), who defines the term "diagnostic" in our context as a series of activities which lead from "detection" to "action." Within this chain of activities, he makes two major categories which, again, correspond to the procedure we use in our questionnaire (Annex II).

\section{1) Analysis}

Detection of unusual items in this particular text type as well as the research for all the necessary information, the identification of specific items in the text and the interpretation of the difficult parts of the text build the core of this step.

\section{2) Planning of the action}

Here the choice of the target to be achieved, the identification of parts of this target, the setting up of a procedure, its executing as well as the improvement of a deficient source text play a major part during this phase.

According to our own experience, a third point has to be added to complete the work, namely

\section{3) Self-evaluation by the learner (see Annex II)}

in which he/she can check the types of mistakes ${ }^{36}$ in order to understand better why they occurred. They might be due, amongst others, to stress, interferences, fear of interferences, or misinterpretation of the ST. 
We became even more interested in cognitive approaches in process-oriented translation teaching when we analysed the translation-process patterns obtained with Translog ${ }^{37}$ and combined them with the interdisciplinary study with the Department of Neurology of the University Hospital of Geneva (HUG). Here are some preliminary results of our study.

\subsubsection{Reasoning by analogy}

According to Nguyen-Xuan (1990), the concept of analogy plays an important role in at least four types of cognitive activities: understanding; reasoning; problem solving and learning.

These activities, in turn, can be divided into source situations and target situations, similar to our source and target texts and languages. So, the knowledge that the learner has about the source situation, which is well anchored in his or her memory, may lead not only to new knowledge concerning the target situation, but may also help to solve certain problems in this new situation and facilitate the transfer of knowledge, taking into account the following concepts:

Understanding: After a thorough reading of the ST, its specificities are listed, cultural particularities and translation problems are highlighted and ideas are put forth to try to resolve them.

Reasoning: There is a discussion about text coherence and logic which may differ between SL and TL. Solving problems of style and language register also depends on the target audience.

Problem solving: Some of the problems spotted can be solved in class. Others, however, will take more time and the solution will not come until the complete text has been worked on. Here again the questionnaire (see Annex I) will help to indicate the most useful strategy to solve the problem.

Learning by analogy: The learner has two options:

a) Either he/she generates knowledge, i.e. new knowledge, through analogy and applies this to the given situation; or

b) An analogy is created through a connecting mechanism in which the subject searches for a given source situation and then, through inference, finds the answer to the problem.

Perceptive learning: This type of learning improves the capacity to differentiate simple perceptive attributes like colours. However, several repetitions are needed to acquire this knowledge. These repetitions are eventually able to modify the brain's structure, as has been shown in scientific studies (Squire, 2001: 78-83). After ten years of using the questionnaire, we have noticed that our students developed automatisms in their capacity as translators which improved the quality of their work and helped them find solutions more quickly.

Emotional learning: This type of learning, which in recent times has been at the core of neurological studies (Damasio 1995), seems to develop outside of the conscious sphere of cognition. Whatever the learning process, however, the emotional factor seems of major importance. What is the relationship of the subject to the theme? To the person who presents it? To the environment in which it is embedded? To the final target of the work, in our case the translation? These items all influence, in turn, the mechanisms responsible for people's "attention span" and "working memory." 38 
In addition, it should be pointed out in this context that recent studies (Fleming et al. 2002; Friederici 2003) have confirmed the hypothesis that women respond more quickly to emotional information of prosody than men. ${ }^{39}$

\section{3. "In situ" study of the translation process}

In the past two centuries our understanding of how the brain and memory function has drastically increased and gained in interest. Methods such as electroencephalography (EEG) and functional magnetic resonance tomography (fMRT) ${ }^{40}$ enable us to visualize to a certain extent the brain while it is working. Memorizing, remembering and forgetting can almost be observed in "real time." Before describing the methods and presenting some results of the ongoing study, let's have a closer look at the brain: ${ }^{41}$

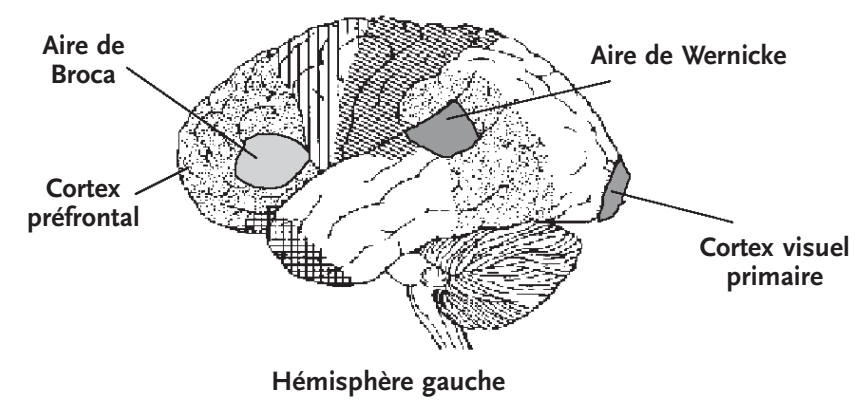

Lateral view of the left hemisphere; Broca area plays a central role in the speech articulation and Wernicke area in the understanding of language.

\subsection{Effects of proficiency on language processing in bilinguals: an interdisciplinary study}

The aim of this ongoing project is to investigate brain activities underlying language processing in the bilingual brain. To achieve this goal, we record the brain's electric activity in highly proficient bilingual students while they perform a well-known reading task. The subjects see sequences of word pairs on a computer screen and after each pair they have to decide whether the two words are semantically related or not. The subject's electrical brain activity (referred to as Event-Related Potentials, ERPs) induced by processing word pairs is computed and analysed separately for semantically related and unrelated word pairs in native (L1) and learned languages (L2) students or subjects. Using methods for the spatio-temporal analysis of electric brain activity developed and performed at the HUG, our objective is to examine individually the processing steps where L1 and L2 differ not only in time but also in space. On the basis of our previous findings (Marwinski: 1998), our predictions were that L1 and L2 processing would differ only in time but not in space. This means that L1 and L2 may influence only at the level of the different steps of information processing but that L1 and L2 rely on similar/overlapping brain structures. This study may provide an important contribution to the study of the bilingual brain and may provide the basis for the development of innovative strategies in language teaching and translation. 
Ultimately, if our hypothesis is validated by this study, that is, if differences in language processing in proficient bilinguals are due to the computation efforts in L2 implying an early pre-lexical or lexical processing step, new teaching methods may be developed, specifically to improve reading (encoding) strategies.

\subsubsection{Overview of the field of research ${ }^{42}$}

Understanding the cognitive and neural processes related to bilingual performance has attracted cognitive neuroscientists for many years. One of the fundamental questions concerns the degree of separation between the different languages in the multilingual brain: are the two languages based on one common or two separate conceptual systems? Some clinical studies (Annoni 2002; Khateb 2002) have reported the impairment of only one language in multilinguals after certain brain lesions. These observations suggested that the processing of two languages relies, at least partially, on different brain areas.

Behavioral studies of bilinguals most often test differences in the semantic aspects (those related to word meaning) of language processing. One oft-used task in these studies is the immediate semantic priming paradigm (or semantic categorization tasks) in which a target word is immediately preceded by a semantically related (SR) or semantically unrelated (SU) prime word. The subjects are asked to decide as quickly and accurately as possible whether the target word is semantically related to the preceding word or not. A "priming effect" (referring to a facilitation in terms of response speed and accuracy) is generally observed when the target word is preceded by a SR prime. This effect, attributed to the pre-activation of a semantic network, is seen in the native and sometimes even more so in the second language.

However, a puzzling issue remains that, while the priming effect is present in both languages, bilinguals (even if proficient) react more slowly when they perform the priming task in their second language. Previous studies of our research group have even shown that the priming effect might disappear in cross-language paradigms, and this observation has led Marwinski et al. (1998) to suggest that different neuronal mechanisms underlie semantic processing in the two languages. ${ }^{43}$

\subsection{Material and Methods}

Twelve right-handed, healthy, German-French bilingual adult students were recruited to participate in this experiment. All participants were 4th-year students at ETI and gave their informed written consent (as required by the HUG ethical committee). Subjects with known neurological or psychiatric antecedents or on medication at the time of the experiment were excluded.

Procedure: The subjects' proficiency in oral and written expression and comprehension in both German and French was first assessed with a battery of tests developed at ETI. The students who were considered to be highly and equally proficient in both languages were retained for the ERP experiment.

Stimuli: The stimuli were chosen from German and French tables of word frequency. The words are concrete, highly frequent nouns of 4 to 8 letters long. German and French words are matched for word length and frequency. As in our preceding experiment, the stimuli list was composed of SR and SU word pairs, and this was 
done for each language. In addition, cross-language SR and SU pairs were formed (1st word in German - 2nd word in French and vice-versa). In SR word pairs, the words are of the same semantic category (furniture, tools, vehicles, vegetables, fruits, persons, animals, etc.). In the SU word pairs, words in each pair belong to different semantic categories. The subjects' task was to determine by pressing a button whether the words in each pair belonged to the same semantic category or not. In contrast with the previous experiment, German and French word pairs were randomly presented in one experimental session.

Behavioral results (accuracy and reaction times) were analyzed in all conditions and statistically compared using repeated measures of variance. Priming type (crossed or non-crossed), language (L1 and L2), semantic relatedness (semantically related and unrelated) were used as subject factors. These experiments were all run in the Department of Neurology at the University Hospital of Geneva by Drs. Annoni and Khateb.

Preliminary results indicate that more extensive cerebral activation is needed for the less proficient language in performing tasks. This means, for our didactic purposes, that mental representations should be fostered prior to the translation task. As far as performance is concerned, the original hypothesis was confirmed that subjects answered more correctly in L1 than in L2. The response time, however, was shorter in beginners than in advanced learners, which indicates that beginners do not possess sufficient knowledge of the difficulties of the text, oversee ambiguities and very often make mistakes due to interferences.

\subsection{Translation process and proficiency}

In this study, language proficiency is evaluated by means of Translog, which has the big advantage of allowing for a visualization of the translation process. It can help the student, who, ideally, can learn through his/her playback to which phase of the task he/she should pay more attention. It is also of major interest to researchers, who can analyze a certain number of issues and evaluate the three phases - orientation, draft, revision - accordingly.

\subsubsection{Materials and Methods}

Students were given a short text of general interest which gave them wide opportunities for using idiomatic expressions. They were trained to work with Translog and then given sufficient time for the translation. The allotted time was two (2h) hours.

A short description and some results are found in Annex III. ${ }^{44}$

\subsubsection{Evaluation of Proficiency}

Two assessors rated the translations and a mean value was given. Personally I used the evaluation criteria described in META (2001): precision, creativity and marketing aspects. Proficiency was evaluated in terms of the overall result and not of each of the three distinct phases of Translog, mentioned above (see scheme in Annex III).

For the present paper we shall limit ourselves to a closer look at the pauses (marked with ${ }^{\star * * * * *}$ ), their frequency and duration, and their impact on the quality of the translation, differentiating between more or less proficient students. 
For this purpose we found it interesting to establish a relationship between the preparatory phase already described by Wallas in 1926 (developed also by Cropley, 1995; Heller, 2001; Rehbinder, 2003), valid for any process-oriented approach in science, and the orientation phase. This preparatory phase deals mainly with the definition of the problem, whatever it may be, and tries to clarify the objective of the task. ${ }^{45}$

The drafting phase can be paralleled with the so-called incubation phase, which - and here we differ in our approach from that of Wallas (1926) - also includes the "illumination" phase ${ }^{46}$ and leads to particular, creative solutions. We are thinking mainly of the creatio ex nihilo, or the unconscious finding of solutions. ${ }^{47}$ The revision phase may be related to the verification phase of Wallas (1926).

The experience has confirmed that less proficient bilinguals tend to be inhibited already in the preparatory phase mainly because they worry about interferences. Hence, it is of major importance during the training, and, in order to be able to call upon all the cognitive abilities of the students, to offer different approaches according to their personalities, to analyze their motivations and their interests and to take into account factors such as memory or capacity to integrate new knowledge and make appropriate use of it at the right moment.

Types and numbers of mistakes after longer pauses in the drafting phase obtained with four less proficient students are illustrated in Figure $2 \mathrm{~A}$ as well as those obtained with four more proficient ones in Figure 2 B. Note that the amplitude of the scales is different.

FIGURE 2 A

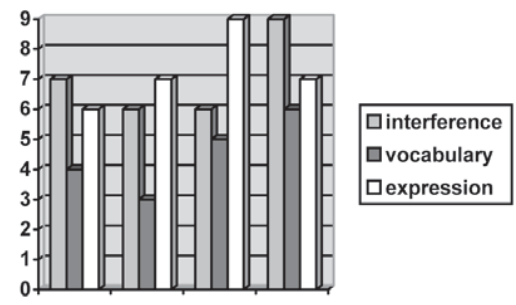

FIGURE 2 B

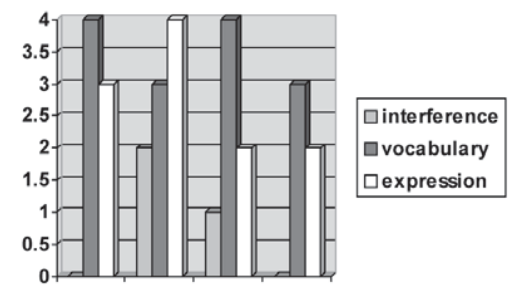

For this paper we show only three out of twelve items as preliminary results, this study being still in progress. Comparing our findings obtained for both populations it can be seen that less proficient students in an advanced stage of their study hesitate more and fear interferences much more than the proficient students and, therefore, we put forward the hypothesis, still to be explored, that these former students rely to a great extent on their memory, but are less skillful in using the connections in their memory. This means that they are unsure of themselves and stick to fixed entities, like vocabulary, but are unable to handle loose entities, like expression, in a satisfactory way. Hence, instead of inferring, they are subject to interferences. The more proficient students made fewer mistakes but, astonishingly, quite a few vocabulary mistakes. As these subjects have a higher analytical sense and detect unusual items in the text more quickly, identify specific terms and are able to interpret difficult parts because they know how to make use of their encyclopaedic knowledge, they automatically care less about what we call fixed entities, be they names, numbers, etc. It would be difficult and fairly pointless to change the way these students work. Therefore, the teacher should encourage their way of functioning and should give them tasks which develop their predictive judgment as mentioned above. 


\subsection{Conclusions and outlook for further research}

The past 25 years of process-oriented research in translation have shown that there are many ways to understand the cognitive processes going on during translation. And yet, much is left open for further research. Thus we need larger groups of students and professionals participating in these experiments, more empirical studies, more statistical analyses in the field of inferences in order to know which are the relevant pedagogical tools to be developed.

We also need to compare so-called distant languages. Above all, we should aim at a large international interdisciplinary study through which more data could be collected, hypotheses could be validated or confuted and new integrative theories in cognitive approaches in process-oriented translation-training could be developed which, in turn, would lead to a pertinent and innovative pedagogical approach.

\section{NOTES}

1. Greek philosopher 515-440 BC.

2. The Grammar of Port-Royal from 1660 is an important example and was based on the concept of logic forms.

3. Described in 1963 as "linguistic principle of relativity."

4. It is interesting to recall the famous drawing by Wittgenstein (1953: 329), representing either a rabbit or a duck, and which he calls a half visual, half cognitive experience. In fact, observer thought he saw a rabbit then thinks he sees a duck. Wittgenstein (1889-1951) is considered by many to be the most important philosopher of the 20th century. The centre of his philosophical considerations was language, because he was convinced that, ultimately, everything is expressed through language.

5. For a detailed specification of the characteristics of human language, see Heringer (2004: 127).

6. The psychological basis of categories and prototypicality is experimentally explored in Rosch (1977, 1999).

7. University of Cornell, USA. For further reading: Lee-Jahnke (1998: 155-183).

8. Where he developed the four ages of translation theory.

9. See: Delisle (2000) Portrait de traducteurs and Delisle (2002): Portrait de traductrices.

10. Or sometimes: "Of how not to translate," if we think of Marx \& Engels (1974).

11. See Greiner (2004) for more information on cultural-historic translation research.

12. The earliest witness we have is probably Cicero, who, in the 1st century BC, said: Not ut interpres sed ut orator. In: Stolze (1994: 14). For further reading: Seele (1995): Nöte, Freiheiten, Absichten: Verfahren des literarischen Übersetzens in der römisch-griechischen Antike; Wissenschaftliche Buchgesellschaft, Darmstadt, especially p. 93.

13. It is our wish to create a network of trainers who could exchange data and find some common denominators in process-oriented translation, which could then be used as structural help for future training classes. Please contact the author of this paper: <hannelore.lee-jahnke@eti.unige.ch>.

14. Recent scientific findings have shown that, for instance, dyslexia varies with language, a fact which should interest translation studies because of the representations. For further reading, see: O'Connor (2004).

15. See Borillo (2002) for further reading.

16. We know of five different memory systems: the procedural memory, which functions through repetition of an action and is situated in the cerebellum and grey nucleus; the semantic memory, which allows us to memorize concepts, the meaning of words independent of their context, and is situated in the neocortex; the representational memory, which helps to memorize an image or a face and allows us to recognize a piece of information more easily, if we have seen it before. It is located in the neocortex. The working memory or short-term memory is used to keep a piece of information for the time of the realization of a task. It is located in the neocortex and prefrontal cortex. The episodic memory, also called autobiographic memory, is located in the prefrontal cortex, the hippocampus and the thalamus.

17. After Houssaye (1993).

18. For further reading, see Prégent (1990): La préparation d'un cours. 
19. For further reading, see Denigot (2004): “Surprises dans l'aire de Broca," Science \& Vie, Hors Série nr. 227, pp. 166-199.

20. At the University of Geneva a pamphlet on the history of Geneva was of major interest and students were invited to visit some historical places with specialists. Their final work can be viewed on the website of the chancellery of Geneva: <www.chancellerie/etat.ch>.

21. Intra-personal interpretation vs inter-personal interpretation.

22. The original English title is: The Uses of Enchantment (1975), but we used the German version.

23. Delisle/Lee-Jahnke/Cormier (1999): Translation Terminology. The definition given there is: "The body of acquired information making up the permanent knowledge of a person."

24. For further reading see Holcbecher (2004).

25. Wissen und dessen Repräsentation, auf $<$ www-user.uni-bremen.de/ $>$.

"Mentale Organisationsformen, die das individuelle Wissen, Prozesse der Veränderung dieses Wissens, die Ableitung von neuem Wissen durch bewusste und unbewusste Schlussfolgerungsprozesse und die Generierung von Handlungsplänen umfasst."

26. For further reading: Wender (1990); Denhière \& Baudet (1992); Risku (1998). On the other hand, mental representations are now one of the most interesting subjects of research at the Centre National de la Recherche Scientifique (CNRS) in France.

27. Denis (2003: 247).

28. See Annex I.

29. Choice of a solution which worked in other circumstances.

30. For further reading: Borillo (2002).

31. These processes will be further analysed in our forthcoming contribution to META 2005.

32. Holland et al. (1986) developed two fundamental hypotheses concerning the inductive activities: a) Problem solving activity, provided this includes also badly defined problems; b) the success or nonsuccess of this problem solving activity will in turn make modifications in the stock of knowledge of the individual.

33. For further reading: Lee-Jahnke (2001) META.

34. A detailed discussion of the evaluation of the different difficulties of the text and their relative importance takes place before the translation. Students establish a text pattern for each text to be translated. This enables them to better understand and weigh the solutions. For a detailed pattern see Annex II.

35. We are thinking in particular of extra-linguistic abilities: world knowledge, specialized knowledge, encyclopaedic knowledge and knowledge of the respective domain, Lee-Jahnke (2004: 95).

36. For the differentiation between mistake and error, see Maschelein et al. (2005) in the present volume.

37. Tool developed by Arnt Lykke Jakobson (1998), University of Copenhagen.

38. Also short-term memory, situated in the neocortex and prefrontal cortex.

39. There was a measurable difference between men and women: women reacted after 200 milliseconds and men after 750 milliseconds.

40. The techniques of functional imaging give access to the brain's metabolism.

41. The schematic drawing above has been kindly provided by Dr. KHATEB, one of the leaders of the project.

42. Bilingualism: terminological and theoretical issues. Simply defined, bilingualism refers to a tool allowing people using two languages to exchange information. The term bilingual, in its widest use, includes all people who have had even minimal exposure to and use a second language. In its most restricted meaning, this term is used to involve people who learned two languages simultaneously since their early childhood and who have native-like and equal proficiency in both languages. According to Brian Harris, they are defined as natural bilinguals compared to individuals who acquired a second language later on in life. While the first definition for Harris includes almost all the human population, the second corresponds more to a cognitive ideal than to a common situation. With a more moderate position we define bilingualism "as the regular use of two (or more) languages and bilinguals are those people who need and use two languages in their everyday lives."

43. For further reading, see Marwinski (1998).

44. For further reading also see the papers in the present volume by Tanja Heiden and Eddie Ronowicz, who are collaborating in the present research project, and who prepared the files.

45. The above-mentioned questionnaires - Annexes I and II - are precisely the tools which help to tackle these two - preliminary - issues of a translation.

46. For further reading, see Wallas (in Rehbinder 2003).

47. It has since been made clear that solutions are not simply found ex nihilo, but that they can be called up more easily by our brain in a relaxed atmosphere (Rehbinder 2003). 


\section{REFERENCES}

Aitchison, J. (1992): Introducing Language and Mind, London, New York, Penguin.

Annoni, J.M., Michel, C.M., Landis, T. and A. Kнатев "Variability of Right Hemisphere Activation During Semantic Word Processing in Aphasic Patients: An Electrophysiological Study in Three Patients," Rev Neurol (Paris), 158 (2002): p. 317-31.

Bettelheim, B. (1977): Kinder brauchen Märchen, Deutscher Taschenbuchverlag.

Borillo, M. and J.-P. Goulette (2002): Cognition et Création, Mardaga, Sprimont.

Chédotal, A. (2002): "Le câblage du cerveau," in Pour la Science, décembre, p. 58-64.

Сноlewa, J. (2002): Der kognitive Ansatz in der klinischen Sprachtherapieforschung, Stauffenburg, Tübingen.

Cleeremans, A. and A. Destrebecqz (2002): “Apprentissage et Conscience," dans Pour la Science, décembre, p. 104-109.

Coirier, P., Gaonac'H, D. and J.-M. Passerault (1996): Psycholinguistique textuelle, Armand Colin, Paris.

Damasio, A. (1994): L'erreur de Descartes, Éditions Odile Jacob, Paris.

Damasio, A. (2002): "La conscience du temps," dans Pour la Science, décembre, p. 110-113.

Damasio, A. (2003): Spinoza avait raison, Éditions Odile Jacob, Paris.

Danks, J. H. (1997): Cognitive Processes in Translation and Interpreting, Sage Publications, London.

Delacour, J. (2002): “Science et Conscience," in Pour la Science, décembre, p. 26-32.

Delisle, J. (2000): Portraits de traducteurs, Les Presses de l'Université d'Ottawa, Ottawa.

Delisle, J. (2002): Portrait de traductrices, Les Presses de l'Université d'Ottawa, Ottawa.

Delisle, J., Lee-Jahnke, H. et M. C. Cormier (ed.) (1999): Terminologie de la traduction, John Benjamins, Amsterdam, Philadelphie.

Denhière, G. and S. BAudet (1992): Lecture - compréhension de texte et science cognitive, Presses Universitaires de France, Paris.

Denis, M. (2003): “Images mentales et pensée," in Le cerveau et la pensée. La révolution des sciences cognitives, 2nd ed. Auxerre Cedex, Sciences Humaines Éditions, p. 247-249.

Descamps, P. (2004): “Les trahisons de la traduction,” in Science \& Vie, Découvertes: du langage aux langues, hors série, Excelsior Publications, Paris.

Dirven, R. and M. Verspoor (2004): Cognitive Exploration of Language and Linguistics, John Benjamins, Amsterdam.

Dortier, J-F. (2001): Le langage, Éditions Sciences Humaines, Auxerre.

Fauconnier, G. and M. Turner (2002): The Way We Think, Basic Books, New York.

Fleiming, G. Rickheit, G. and H.M. Müller (2002): Neurokognition der Sprache, Stauffenburg Verlag, Tübingen.

Flores D’Arcais and B. Giovanni (1970): Advances in Psycholinguistics, Research Papers presented at the Bressanone Conference on Psycholinguistics, Padova/Amsterdam, North Holland.

Friederici, A., D. (2003): “Der Lauscher im Kopf," in Gehirn \& Geist, Spektrum der Wissenschaft, Nr 2, p. 43-45.

Greiner, N. (2004): Übersetzung und Literaturwissenschaft, Narr Studienbücher, Tübingen.

Heringer, H. J. (2004): Interkulturelle Kommunikation, A. Francke, Tübingen and Basel.

Holcbecher, S. (2004): "Interferenzen, Kognition - Translation: Stellenwert mentaler Repräsentationen im Übersetzungsprozess,” unpublished; H. LeE-JAhnKe und T. Heiden (dir.).

Holland, J.H. and Holyoak, K.J. et al. (1986): Induction, ed. MIT, Press, Cambridge.

Houdé, O., Kayser, D., Koenig, O., Proust, J. and F. Rastier (2003): Diccionario de ciencias Cognitivas, Amorrortu, Buenos Aires.

HoussaYé, J. (1993): "Le triangle pédagogique ou comment comprendre la situation pédagogique," in J. Houssayé (ed.) La pédagogie une encyclopédie pour aujourd’hui, ESF, Paris, p. 54-67.

Imbert, M. (2002): “Perception visuelle et conscience," in Pour la Science, décembre, p. 90-95.

JäÄskeläInen, R. (1987): "What Happens in a Translation Process: Think-Aloud Protocols of Translation," Savolinna, University of Joensuu, unpublished thesis. 
Khateb, A., Annoni, J.M., Landis, T., Pegna, A.J., Custodi, M.C., Fonteneau, E., Morand S.M. and C.M. Michel, "Spatio-Temporal Analysis of Electric Brain Activity During Semantic and Phonological Word Processing," International Journal of Psychophysiology, 32 (1999), p. 215-231.

Khateb, A., Michel, C.M., Pegna, A.J., Landis, T. and J.M. Annoni, "New Insights into the Stroop Effect: A Spatio-temporal Analysis of Electric Brain Activity," [In Process Citation], Neuroreport, 11 (2000): 1849-1855.

Khateb, A., Pegna, A.J., Michel, C.M., Custodi, M.C., Landis, T. and J.M. Annoni, "Semantic Category and Rhyming Processing in the Left and Right Cerebral Hemisphere," Laterality, 5 (2000) p. 35-53.

Khateb, A., Pegna, A.J., Michel, C.M., Landis, T. and J.M. Annoni, "Dynamics of Brain Activation During an Explicit Word and Image Recognition Task, an Electrophysiological Study," Brain Topogr, 14 (2002) p. 197.

Kleiber, G., Kochendörfer, G., Riegel, M. and M. Schecker (1999): Kognitive Linguistik und Neurowissenschaften, Gunter Narr Verlag, Tübingen.

KöNIGs, F. (1996): Les processus de la traduction, META, vol. 41, p. 5-184.

Krings, H.-P. (1986): Was in den Köpfen von Übersetzern vorgeht: Eine empirische Untersuchung zur Struktur des Übersetzungsprozesses an fortgeschrittenen Französischlernern. Narr Verlag, Tübingen.

Ladmiral, J.-R. (1999): "Approches en théorie de la traduction," in Coll. "Sources - Cibles," H. Awaiss et J. Hardane (ed.), Université Saint Joseph, Beyrouth, Libanon, p. 11-47.

Lee-JAhnke, H. (1998): "L'introspection à haute voix: recherche appliquée," in Enseignement de la traduction et traduction dans l'enseignement, J, Delisle and H. Lee-Jahnke (ed.), Les Presses de l'Université d'Ottawa, Ottawa, p. 155-183.

Lee-Jahnke, H. (2001): “Aspects pédagogiques de l'évaluation en traduction,” in META 46 (2), H. LeE-JAHnKe (ed.), p. 258-272.

Lee-Jahnke, H. (2004): "Le défi de la formation des traducteurs," in FORUM, vol. 2 nr. 1, April, Presses de la Sorbonne Nouvelle, Paris, p. 91-105.

Marx and Engels (1974): Über Sprache, Stil und Übersetzung, Dietz Verlag, Berlin.

Marwinski, D. (1998): "Übertragungsstrategien und -Fehler bei Anfängern und Fortgeschrittenen Lernern," unpublished diplomawork; H. LeE-JahnKe (dir.).

Masschelein, D. and W. Verschueren (2005): "Vers un apprentissage semi-autonome du processus de la traduction" (in print) META, special issue on process-oriented translation and interpretation; Hannelore LeE-JAhnKe (ed.), Montréal.

Nguyen-Xuan, A. (1990): "Le raisonnement par analogie," in Traité de Psychologie cognitive, Éd. Dunod, Paris, p. 57-63.

O'Connor, A. (2004): "Dyslexia Varies with Language," in International Herald Tribune, September 9 th, p. 9.

Osaka, N. (2003): Neural Basis of Consciousness, John Benjamins, Amsterdam.

Paradis, M. (2004): A Neurolinguistic Theory of Bilingualism, John Benjamins, Amsterdam.

Peirce, C. (1931-1958): Collected Works, Cambridge, Mass., Harvard University Press.

Peirce, C. (1931-1935): Collected Works, Cambridge, Mass., Harvard University Press, Vol. 5, p. 400.

Perrenoud, P. (1984): La fabrication de l'excellence scolaire: du curriculum aux pratiques de l'évaluation, Genève, Droz.

Peterfalvi, J.-M. (1974): “Introduction à la psycholinguistique," in coll. “Le psychologue," nr. 43, 2nd ed. Paris, Presses Universitaires de France.

Prégent, R. (1990): La préparation d’un cours, Montréal, University Press.

Rasmussen, J. (1986): Information Processing - and Human Machine Interaction, Ed. North Holland, Amsterdam.

Rickheit, G. and H. Strohner (1993): Grundlagen der kognitiven Sprachverarbeitung: Modelle, Methoden, Ergebnisse, Tübingen, Francke. 
Rickheit, G., Sichelschmidt, L. and H. Strohner (2002): Psycholinguistik, Stauffenburg, Tübingen.

Risku, H. (1998a): Translatorische Kompetenz, Kognitive Grundlagen des Übersetzens als Expertentätigkeit. Studien zur Translation, Bd. 5, Snell-Hornby, Mary (ed.), Stauffenburg Verlag, Tübingen.

Risku, H. (1998b): "Kognitionswissenschaft," in Mary Snell-Hornby, Hand Hönig/Paul Kussmaul, P. A. Sснмiтt (eds.) Handbuch Translation, Stauffenburg Verlag, Tübingen, p. 280-285.

Rosch, E. (1977): "Human categorization," in N. Warren (ed.), Studies in Cross-Cultural Psychology, Vol. 1. New York, Academic Press, p. 3-49.

Rosch, E. (1999): “Reclaiming Concepts," in Journal of Consciousness Studies 6, p. 61-77.

Sснnотz, W. (1994): Aufbau von Wissensstrukturen, Untersuchungen zur Kohärenzbildung beim Wissenserwerb mit Texten, Beltz Psychologie Verlags Union, Weinheim.

Seele, A. (1995): Nöte, Freiheiten, Absichten: Verfahren des literarischen Übersetzens in der römisch-griechischen Antike, Wissenschaftliche Buchgesellschaft, Darmstadt

SÉguinot, C.(1989): “The Translation Process: An Experimental Study," in The Translation Process, C. SÉguinot (ed.) H.G. Publications, Toronto, p. 21-53.

Singer, W. (2002): "Synchronisation neuronale et représentations mentales," in Pour la Science, décembre, p. 74-79.

Squire, L. and E. Kandel (2001): "La mémoire non consciente," in Pour la Science, Avril-juillet, special issue: La mémoire, le jardin de la pensée, p. 78-83.

STolze, R. (1994): Übersetzungstheorien, Eine Einführung, Narr Vlg. Tübingen.

Tirkkonen-Condit, S. (1989): "Professional Versus Non-Professional Translation: A ThinkAloud protocol study," in The Translation Process, C. SÉGuInot (ed.) H.G. Publications, Toronto, p. 73-84.

Ungerer, F. and H.-J. Schmid (1994): Language and Understanding, Oxford, Oxford University Press.

VAndeloise, C. (2003): Langues et cognition, Lavoisier, Paris.

Whorf, B. (1946): Language, Thought and Reality: Selected Writings of Benjamin Lee Whorf, J. Caroll (ed.), Cambridge, Mass., MIT Press.

Wildgen, W. (2004): The Evolution of Human Language, John Benjamins, Amsterdam.

Wittgenstein, L. (1953): Investigations philosophiques, Paris, Gallimard.

Wu, Qing (2002): "Interaction Between Language and the Mind Through Translation: A Perspective from Profile/Base Organization," in Meta 47-4, Montréal, Les Presses de l'Université de Montréal.

\section{ANNEX I}

\section{Autoevaluation questionnaire}

A) Eigenbewertung, Erstlektüre nach Übersetzung

c) Textuel bedingte Schwierigkeiten: Terminologie

d) Dokumentationsbezogene Schwierigkeiten

ja nein

e) Gefundene Lösungen für die genannten Schwierigkeiten

ja nein

B) Zweitlektüre, unter besonderer Berücksichtigung des Problemmoments beim Translations prozess (konnte die im AT enthaltene Information mit bereits vorhandenen Kenntnissen assoziiert werden, oder musste das Hintergrundwissen erst erarbeitet werden)?

Wann ist der Fehler eingetreten?

a) Verständnis des AT?

b) Transposition AT in ZT

(Problematik der Formulierung im AT; Formulierung und Gedankengang im AT eigentlich klar und bekannt, jedoch falsche Wiedergabe: Beeinflussung durch Kontext, bereits früher aufgenommene Informationen).

c) Unglückliche Wendung im ZT (lexikalisch oder jargonbedingt) 
B) Welche Strategie haben Sie zur Lösung des Problems angewandt?

a) Achievementstrategie: durch Hilfsmittelbenutzung, durch Paraphrasen

b) Defaultstrategie: Rückgriff auf Erfahrung und Wahl einer Standardübersetzung, die in anderen Zusammenhängen geklappt hat.

c) Reduktionsstrategie: Sie machen Abstriche von Ihrem Übersetzungsziel und Übersetzen reduziert oder ließen im Extremfall den fraglichen Ausdruck weg.

Lösungen für die Beseitigung des Problemmoments:

C) Fremdbewertung

1) Textuel bedingte Schwierigkeiten: Terminologie, Jargon

2) Dokumentationsbezogene Schwierigkeiten

Lösungsvorschläge:

\section{ANNEX II}

\section{Lastenheft ${ }^{*}$}

Ausgangstext (AT)

\begin{tabular}{|l|l|}
\hline Sprache & • Französisch \\
\hline Quelle & $\begin{array}{l}\text { ・ Vos, Anton: „Une thérapie génique parvient à soigner des cellules } \\
\text { d'un cœur souffrant d'insuffisance“; in: Le Temps vom 6.4.2004. }\end{array}$ \\
\hline
\end{tabular}

Zieltext (ZT)

\begin{tabular}{|c|c|}
\hline Sprache & - Deutsch \\
\hline Termin & - Montag, 17.05 .2004 \\
\hline Paralleltexte & $\begin{array}{l}\cdot \text { „Patientenleitlinie Herzschwäche (=Herzinsuffizienz “ } \\
\rightarrow \underline{\text { http://www.patientenleitlinien.de/Herzinsuffizienz/body }} \\
\underline{\text { herzinsuffizienz.html }} \\
\text { (Patientenleitlinien) } \\
\text { • „Herzschwäche“ } \\
\rightarrow \underline{\text { http://www.gesundheitpro.de/partner/surfmed/krankheiten/ }} \\
\underline{\text { herz und kreislauf/herzschwaeche }} \\
\text { (GesundheitPro.de - Der Online-Service von Apotheken Umschau und } \\
\text { Gesundheit) } \\
\text { • „Herzinsuffizienz (Herzschwäche)“ } \\
\rightarrow \text { http://www.netdoktor.de/krankheiten/fakta/herzinsuffizienz.htm } \\
\text { (netdoktor.de) } \\
\text { • „Herzinsuffizienz“ } \\
\rightarrow \text { http://www.m-ww.de/krankheiten/herz_kreislauf_erkrankungen/ } \\
\text { herzinsuffizienz.html } \\
\text { (Medicine Worldwide) }\end{array}$ \\
\hline Medium & $\begin{array}{l}\text { - Medizinischer Artikel in einer Tageszeitung der französischsprachigen } \\
\text { Schweiz (Le Temps) }\end{array}$ \\
\hline Layout & $\begin{array}{l}\text { - Seite in vier Spalten gegliedert; Übertitel und Titel; hervorgehobene, } \\
\text { eingerahmte Textstellen sowie eine Abbildung des Herzen lockern den } \\
\text { Text auf und sprechen den Leser an }\end{array}$ \\
\hline
\end{tabular}

* () Hannelore Lee-Jahnke. 


\begin{tabular}{|c|c|}
\hline Funktion & - auf ansprechende Weise informieren (informativer Text) \\
\hline Zielpublikum & $\begin{array}{l}\text { - allgemeines, an wissenschaftlichen - hier medizinischen - Themen } \\
\text { interessiertes Zielpublikum }\end{array}$ \\
\hline Thema & $\begin{array}{l}\text { - Gentherapie zur Behandlung von Zellen eines an Insuffizienz } \\
\text { leidenden Herzens }\end{array}$ \\
\hline Inhalt & $\begin{array}{l}\text { - Amerikanische Forscher haben eine Gentherapie eingesetzt, um } \\
\text { beschädigte Herzzellen zu behandeln. Die Muskelzellen, die Patienten } \\
\text { mit einer Herzinsuffizienz entnommen worden waren, gewannen nach } \\
\text { der Behandlung ihre Kontraktionsfähigkeit sowie andere funktionelle } \\
\text { Eigenschaften zurück, die sie verloren hatten. Dieses Ergebnis wurde } \\
\text { erreicht, indem ein „therapeutisches Gen“ mit Hilfe eines vorher } \\
\text { unschädlich gemachten Virus in die Zellen eingesetzt wurde. }\end{array}$ \\
\hline Kohärenz & $\begin{array}{l}\text { - Der „rote Faden“ des Textes bildet die vom amerikanischen } \\
\text { Forscherteam eingesetzte Gentherapie, deren einzelne Phasen in } \\
\text { chronologischer Reihenfolge erläutert werden; die einzelnen Absätze } \\
\text { und Untertitel dienen dabei als Sinneinheiten und enthalten zum Teil } \\
\text { zusätzliche, für den Leser interessante Informationen zur } \\
\text { Herzschwäche. }\end{array}$ \\
\hline Stil/Register & $\begin{array}{l}\text { - sachlicher Stil; allgemein verständliche Sprache, die allerdings } \\
\text { zahlreiche medizinischen Fachtermini enthält („gène thérapeutique“, } \\
\text { „insuffisance cardiaque“, „virus rendu inoffensif“, „étude clinique“, } \\
\text { „kinase bêta-adrénergique 1“ usw.) }\end{array}$ \\
\hline $\begin{array}{l}\text { kulturspezifische } \\
\text { Ausdrücke }\end{array}$ & $\begin{array}{l}\text { - American Heart Association, Service de chirurgie cardio-vasculaire } \\
\text { du Centre hospitalier universitaire vaudois (CHUV) } \\
\rightarrow \text { Namen von Institutionen, die in der AS belassen und kursiv } \\
\text { gedruckt werden müssen, da es im Deutschen keine exakten } \\
\text { Entsprechungen gibt }\end{array}$ \\
\hline $\begin{array}{l}\text { spezifische } \\
\text { Schwierigkeiten }\end{array}$ & $\begin{array}{l}\text { - korrekte Wiedergabe der medizinischen Fachausdrücke } \\
\text { (Terminologie) } \\
\text { • gerade für Laien ist es am Anfang nicht ganz einfach, die in der } \\
\text { medizinischen Fachsprache geläufigen Kollokationen im Deutschen } \\
\text { idiomatisch und korrekt wiederzugeben; wichtig ist es hier für den } \\
\text { Übersetzer zu lernen, welches Verb jeweils mit welchem Substantiv zu } \\
\text { verwenden ist (z.B. eine Therapie „einsetzen“, ein Gen in eine Zelle } \\
\text { „einführen“/“einbringen“/“transportieren“ usw.) } \\
\text { - Wenn in einem solchen vulgarisierten Fachtext eine Fachperson zitiert } \\
\text { wird, ist es im Deutschen im Gegensatz zum Französischen nicht } \\
\text { üblich, die Berufsbezeichnung oder den Titel (z.B. „Forscher“/ } \\
\text { "Professor“ am...") anzugeben; es reicht hier, wenn der Name und die } \\
\text { Institution genannt wird (z.B. „Walter Koch vom Duke University } \\
\text { Medical Center in Durham in den Vereinigten Staaten“) } \\
\text { - Beachtung der in der französischen Sprache typischen Satzstrukturen, } \\
\text { die an die deutsche Syntax anzupassen sind; so muss z.B. der Satz } \\
\text { „[des cellules] ont été prélevées sur les coeurs récupérés sur dix } \\
\text { personnes ayant subi une transplantation cardiaque“ wiedergegeben } \\
\text { werden mit „[Zellen] wurden den Herzen von zehn Patienten } \\
\text { entnommen, an denen eine Herztransplantation durchgeführt worden } \\
\text { war“; wir sehen also, dass der gleiche Inhalt aus einer anderen } \\
\text { Perspektive wiedergegeben wird. }\end{array}$ \\
\hline
\end{tabular}




\section{ANNEXE III}

Translog

Orientation 0'00' - 02'17'"

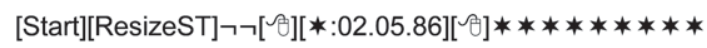

Drafting 02'17" - 31'33"

Schokolade $\bullet * *$ eine $\bullet[*: 12.76]$ •Messe**! $\sqrt{y * * * * \otimes A n n e-}$

Cécile Sanchez $\forall * * * *$ Nicht $\bullet$ weniger $\bullet$ als $\bullet 1000 * \otimes \otimes * 000 * *$ Beus $\otimes \otimes$ sucher $\bullet$ werden $\bullet d$ ieses Wochenende $\bullet a m \bullet * 9 . * * * *$ Europäsi $\otimes \otimes i s c h e n \bullet * * * * * * * *[\vartheta] * n \bullet \operatorname{der} * *[\vartheta] * \mathrm{~S}$

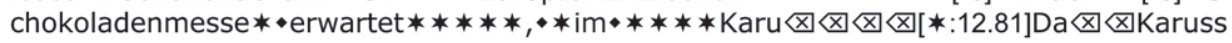
el•des $\bullet$ Louver $\otimes \otimes$ re. $\bullet[*: 28.09]$ Französiss $\otimes$ che $* * *$ Fabrikante*n* $*$ und $\bullet[*: 20.05][\vartheta] * *[$

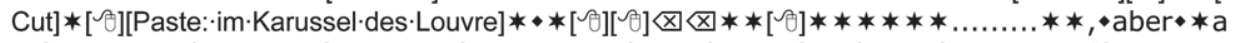
uch $*$ russische $* *, \bullet$ jab $\otimes$ panische $\bullet$ u $\otimes \otimes, \bullet$ deutsche $\bullet$ und $\bullet$ italienische $* * * * *$ Cho $\otimes \otimes$

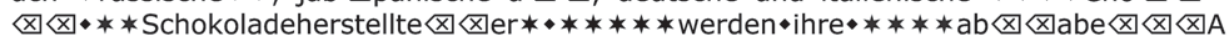
barten $\bullet$ von $\bullet$ Schokolade $* *$ vor $\otimes \otimes \otimes$ präsentieren. $\bullet \otimes * * \otimes *: \bullet * * * * * * * * *$ die $\bullet$ S $\otimes$ $\otimes \otimes \otimes \otimes$ Schokolade $\bullet$ und $* * * * * * *$ der $\bullet$ gerechte $\bullet$ Handel, $\bullet * *$ biologische $\bullet$ Schokolade, $\bullet$ $*$ sch $\otimes \otimes \otimes$ Schokolade******unm $\otimes \mathrm{d} \bullet * *$ die $*$ Frauen, $\bullet[*: 14.45]$ das $* * * * * * * * *$

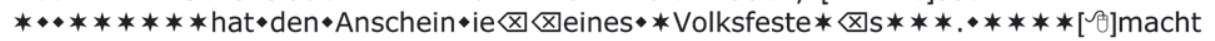

Legend: $* * * * * *=$ loose entities; $* * * *=$ fixed entities 